https://doi.org/10.18485/kud_kiaz.2019.ch42

Рейхан Джафарова

Азербайджанский университет языков

ведущий научный сотрудник «Центра Россиеведения»

преподаватель кафедры «Международные отношения»

\title{
КОНСТИТУЦИОНАЛИЗМ В АЗЕРБАЙДЖАНСКОЙ РЕСПУБЛИКЕ КАК РЕЖИМ КОНСТИТУЦИОННО- ГО ГОСУДАРСТВЕННОГО ПРАВЛЕНИЯ
}

\section{SUMMARY}

In this article author will try to reveal the essence of the constitutionalism in the Republic of Azerbaijan as a regime of the constitutional state government.

In the article provided components of the constitutionalism in the aspect of government system, the major ones are democratic institutes of power, constitutional system of democratic values protection, the rights and freedoms of man and citizens, etc.

Key words: Constitution, constitutionalism, democratic society, constitutional principles.

Понятие о конституции государства тесно связано с представлением о том, что такое конституционализм. Одной из сущностных черт конституционализма в его современном понимании являются конституционные идеи и ценности, основанные на достигнутом высоком уровне развития демократии: осознание общности и неразрывности интересов общества и государства и соответственно необходимости консенсуса в вопросах социального и государственного устройства, управления делами государства и общества; признание приоритета человеческой 
жизни и достоинства личности при решении вопросов властвования; идея народовластия и основанный на ней демократический порядок формирования основных государственных институтов; верховенство права и т.д. Эти идеи должны не просто существовать в обществе, а быть принятыми им, твердо укорениться в общественном сознании, пройти так называемую общественную легитимацию. Каждый из этих принципов в той или иной степени способствует развитию конституционализма. Вследствие чего, считаем, что при определении места и роли конституционализма в развитии правового государства важно особенно подчеркнуть значимость конституции. По мнению А. Шайо, конституционализм - это ограничение власти с целью общественной стабильности. Но по нашему мнению, ограничение власти не всегда гарантирует общественную стабильность. Тем не менее, ограничение власти, которое осуществляется ради эффективного и оперативного управления, может отвечать требованиям общественной стабильности.

Современные конституции закрепляют присущие обществу ценности и элементы национального менталитета. Отметим, что в этом вопросе особенности различных государств не имеют существенного значения. Элементы ценностей, имеющие место в Конституции, одинаково отвечают интересам всех социальных слоев. На современном этапе Конституции определяют общечеловеческие ценности и дают им совсем иной облик, поднимая их на новый уровень. Таким образом, формируются новые приоритеты свободного общества, в котором действующая конституция обуславливает создание всех условий для достойной жизни членов общества. Конституционализм можно рассмотреть как систему важных механизмов, которые обеспечивают применение юридически регулирующих принципов в государстве.

Анализируя особенности конституционализма в Азербайджанской Республике, важно обратить внимание 
на основные моменты Конституции азербайджанского государства. Прежде всего, отметим, что с точки зрения успешного применения принципов государственности и развития строительства демократического общества, изучение теории и практики конституционализма в Азербайджанской Республике имеет огромное значение. Как известно, азербайджанский конституционализм имеет свои исторические корни. В основном считается, что история азербайджанского конституционализма начинается с 1918-ого года. С формированием Народного Джумхурията были приняты законодательные акты, которые отражали важные принципы государственности и государственного управления, хотя Конституция так и не была принята. Но можно утверждать, что основа конституционализма Азербайджана была заложена не в советский период, а при первой демократической республике. «Декларация независимости» или «Акт о независимости Азербайджана» включала в себя некоторые важные элементы конституции. С принятием первого конституционного акта азербайджанская государственность была объявлена в форме «Народного Джумхурията». В этом правовом и политическом документе помимо провозглашения независимости Азербайджана, находили свое отражение также основные принципы деятельности государства, что свойственно настоящей Конституции. В Декларации независимости имели место также атрибуты демократического государства.

В советский период в Азербайджане наблюдались лишь определенные элементы конституционализма. Но важно отметить, что вопрос существования самого конституционализма в советский период был весьма спорным. Во-первых, в ограничении государственного управления азербайджанская Конституция не играла значимой роли. Во-вторых, Конституция Азербайджана советского периода не отражала интересы страны, ее особенности и ценности азербайджанского народа. 
Первым шагом в создании конституционного государства в нашей стране стало принятие 18-го октября 1991-го года Конституционного Акта «О государственной независимости Азербайджанской Республики», посредством которого была заложена основа формирования азербайджанского конституционализма, т.е. этот исторический акт стал началом подготовки новой Конституции независимой Азербайджанской Республики. Отметим, что после провозглашения независимости в 1991 году и до принятия новой Конституции 1995 году, действовали положения Конституции 1978-го года, соответствующие положениям Конституционного Акта «О государственной независимости Азербайджанской Республики», в котором закрепились главные принципы конституционного строя. Например, «Суверенная власть в Азербайджанской Республике принадлежит азербайджанскому народу» (статья 10, часть 1). Также, в первой части статьи 12 отмечается: «Азербайджанский народ создает независимое, светское, демократическое и унитарное государство». В статье 13 имеется положение о том, что государственная власть в Азербайджанской Республике основывается на принципе разделения властей. В статье 32 Акта отмечается: «Настоящий Конституционный Акт служит основой для разработки новой Конституции Азербайджанской Республики».

Таким образом, с момента приобретения независимости азербайджанского государства, сложные процессы, происходящие в общественно-политической жизни страны, а также конкретные положения Конституционного Акта «О государственной независимости Азербайджанской Республики» 1991-го года выступали в качестве предпосылок для принятия новой Конституции.

12 ноября 1995 года путем референдума была принята первая Конституция независимого Азербайджана. Как известно, для разработки новой Конституции была создана специальная комиссия, во главе которой стоял 
сам общенациональный лидер Гейдар Алиев. Эта Конституция положила основу государственного строительства в Азербайджане. По своей структуре Конституция Азербайджанской Республики 1995 года состоит из преамбулы, 5-ти разделов, 12-ти глав и 158-и статей.

Основная качественная особенность Конституции Азербайджана заключается в том, что каждая статья Конституции имеет свое название. В конституциях других государств указывается только лишь номер статьи.

С принятием новой Конституции Азербайджанской Республики в стране появились реальные предпосылки становления и развития конституционализма. Принятие Конституции в 1995 году обусловило необходимость появления теории и практики конституционализма. Как для любого современного государства, так и для независимого Азербайджана Конституция является главной ценностью, т.к. конституционные принципы являются центральными определяющими элементами общественных отношений. Именно общественные отношения выступают в качестве объекта конституционно-правового регулирования. Отметим, что конституционные принципы относятся не только к конституционному строю государства. Они относятся также к политической системе, территориальной организации государства, правовому статусу человека, экономической системе и т.д.

Эти вопросы были затронуты и в заключительной речи Президента Ильхама Алиева на заседании Кабинета Министров, посвященного итогам социально- экономического развития в 2014 году и предстоящим задачам. Он отметил: «Роль Азербайджана постепенно возрастает. Господствующая в нашей стране общественно - политическая обстановка, мультикультурализм, религиозно - национальная терпимость, открытость для мира - все эти факторы сегодня нужны Европе, миру. Потому что в реальной жизни мы, к сожалению, зачастую видим совершенно иную картину - кровавые столкновения, тер- 
роризм, вражду, двойные стандарты и пр. Азербайджан же предлагает свою модель развития. Эта модель открыта для всех. Экономическая модель - сегодня мы говорили об этом. То есть это - уникальная модель экономического развития. Модель политических реформ. Думаю, Азербайджан может служить примером, потому что, проводя экономические реформы, мы одновременно придаем большое значение и политическим реформам. Созданы все демократические институты. Обеспечены все свободы - свободы слова, свобода собраний, свобода совести, свобода печати, свобода интернета, свобода вероисповедания. Эти свободы не только обеспечены, они одновременно являются образом нашей жизни, государственной политикой».

Одним словом, конституционные принципы подчиняют себе всё содержание конституции государства. Эти положения очередной раз свидетельствуют о высокой значимости новой Конституции для независимой Азербайджанской Республики, в политической жизни которой до принятия Основного закона государства царил глубокий хаос и наблюдалась неопределенность в политическом и экономическом планах. Именно, после принятия Конституции в 1995 году появилась реальная возможность регулирования общественно-политических отношений в стране.

Конституция Азербайджанской Республики заимствовала лучшие элементы нашей истории и использовала эффективные механизмы функционирования современных государств.

Список использованной литературы

Добрынин Н.М. Основы конституционного (государственного) права РФ: 100 вопросов и ответов. Практическое руководство / Новосибирск: Наука, 2018. - 811 с. 
Шайо А. Самоограничение власти. М., Юристъ,1999, 534 с.

Классен А. Н. Конституция России и конституционализм XXI века: перспективы развития// Проблемы и вопросы конституционного и административного права. 2013, Том 13, № 4, с.93-97.

Aslanov T. Müasir Azərbaycanın dövlət quruculuğunda Konstitusiya Məhkəməsinin rolu// www.gun.az/latest/68390// 02 Aprel 2013 [22:10]

Юсифзаде С. З. Первая Азербайджанская Республика: история, события, факты англо-азербайджанских отношений. Б., Маариф, 1998, 208 с.

Конституционный Акт Азербайджанской Республики «О Государственной Независимости Азербайджанской Республики». Баку, 18 октября 1991 г.

Azərbaycan Respublikasının Dövlət Müstəqilliyi haqqında: Konstitusiya Aktı. 18 oktyabr, 1991-ci il.//Azərbaycan Respublikasının Qanunlar Külliyat1, B., 2001, c.1, s.90-96.

Azərbaycan Respublikasının Prezidenti İlham Oliyev multikulturalizmin Azərbaycan modeli haqqında: Seçilmiş fikirlər. Bakı: Bakı Beynəlxalq Multikulturalizm Mərkəzi, 2107. - 528 s.

Юрчук В.С. История политических и правовых учений. Издательство: МИЭМП, 2010 г., 187с.

\section{РЕЗЮМЕ}

В данной статье автор попытается раскрыть сущность конституционализма в Азербайджанской Республике как режима конституционного государственного правления. В статье даются составные части конституционализма в аспекте системы правления, основными из которых являются демократические институты власти, конституционная система защиты ценностей демократии, прав и свобод человека и гражданина и др.

Ключевые слова: Конституция, конституционализм, демократическое общество, конституционные принципы. 